\title{
Benthic foraminiferal extinction and repopulation in response to latest Paleocene Tethyan anoxia
}

\author{
$\left.\begin{array}{l}\text { Robert P. Speijer* } \\ \text { Birger Schmitz }\end{array}\right]$ - Department of Marine Geology, Göteborg University, 41381 Göteborg, Sweden \\ Gijsbert J. van der Zwaan Department of Geology, Utrecht University, P.O. Box 80021, 3508 TA Utrecht, The Netherlands, and \\ Department of Biogeology, Nijmegen University, Toernooiveld 1, 6525 ED Nijmegen, The Netherlands
}

\begin{abstract}
The latest Paleocene benthic foraminiferal extinction event has been studied in two marlstone successions in the Tethys: at Wadi Nukhl (Egypt) and Torangly (Turkmenistan). Both sections yield a sapropelic layer at the level of the extinction event. At Nukhl, this layer underlies a thin calcareous bed that has also been found in other Middle East upper Paleocene sections. With the onset of anoxia at the Tethyan sea floor, the aerobic and oligotrophic Gavelinella beccariiformis deep-sea community collapsed. Eutrophic-to-mesotrophic and low-oxygen conditions, most likely resulting from enhanced organic carbon fluxes to the sea floor, triggered an $\sim 100-200$ k.y. repopulation sequence, marked by downslope migration of several neritic communities that were dominated by opportunistic and tolerant taxa. The initial ecosystem restoration was completed when an aerobic and oligotrophic Nuttallides truempyi deep-sea community became established. We suggest that this repopulation mode could be typical for the central Tethys.
\end{abstract}

\section{INTRODUCTION}

Near the end of the Paleocene, during the most severe turnover in deep-sea benthic foraminifera of the past 90 m.y. (Tjalsma and Lohmann, 1983), about $40 \%$ of all deep-sea taxa became extinct within a very short ( 10 k.y.) time span (Kennett and Stott, 1991; Kaiho, 1994). This extinction event and its potential causes (e.g., high-latitude warming and oceanic circulation reversal) have been discussed extensively (for reviews, see Thomas and Shackleton, 1996; Thomas, 1997). In contrast to the cosmopolitan distribution of the Gavelinella beccariiformis community that became extinct, deep-sea communities directly following this event indicate enhanced biogeographic variation, and early repopulation communities mostly consisted of thin-walled or agglutinated deep-sea survivor taxa (Thomas, 1997). In general, deep-sea records (e.g., Thomas and Shackleton, 1996) show that characteristic early repopulation taxa were indigenous, although less common, before the extinction event. Repopulation on the bathyal continental margin could have progressed much differently because of potential migratory connections to the shelf and the generally greater environmental tolerance of neritic taxa.

Speijer (1994) reported on the benthic extinction event in the bathyal ( 600 m) Wadi Nukhl (Abu Rudeis) section (western Sinai, Egypt), where a Gavelinella beccariiformis community was replaced by a Nuttallides truempyi community, similar to many South Atlantic and Indian Ocean sites (Tjalsma and Lohmann, 1983; Thomas, 1997). The benthic extinction event ap-

*Present address: FB 5-Geosciences, Bremen University, P.O. Box 330440, 28334 Bremen, Germany. peared to coincide with a calcareous bed within a marlstone succession (Speijer, 1994), similar to observations of other Middle East sections (Schmitz et al., 1996, 1997). Closer examination of the Nukhl section, however, revealed a unique sapropelic bed, partly laminated, just below the calcareous bed, indicating oxygen deficiency within the benthic extinction event interval. A similar and coeval lithologic succession was found in the bathyal $(\sim 800 \mathrm{~m})$ Torangly section (Turkmenistan; Muzylöv et al., 1995) on the opposite side of the Tethys. Here we document benthic foraminiferal extinction and repopulation patterns at these two localities.

\section{STRATIGRAPHY}

The studied sequence at Nukhl spans the basal part of calcareous nannoplankton Zone NP9 to the top of planktic foraminifera Zone P5 (corresponding to the lower part of Zone NP10). The benthic extinction event interval is situated at the base of the sapropelic bed and coincides with a sharp negative whole-rock $\delta^{13} \mathrm{C}$ excursion (Fig. 1). The latter is found globally, enabling interbasin correlations (Kennett and Stott, 1991; Pak and Miller, 1992; Schmitz et al., 1996; Thomas and Shackleton, 1996). For more details on bio-

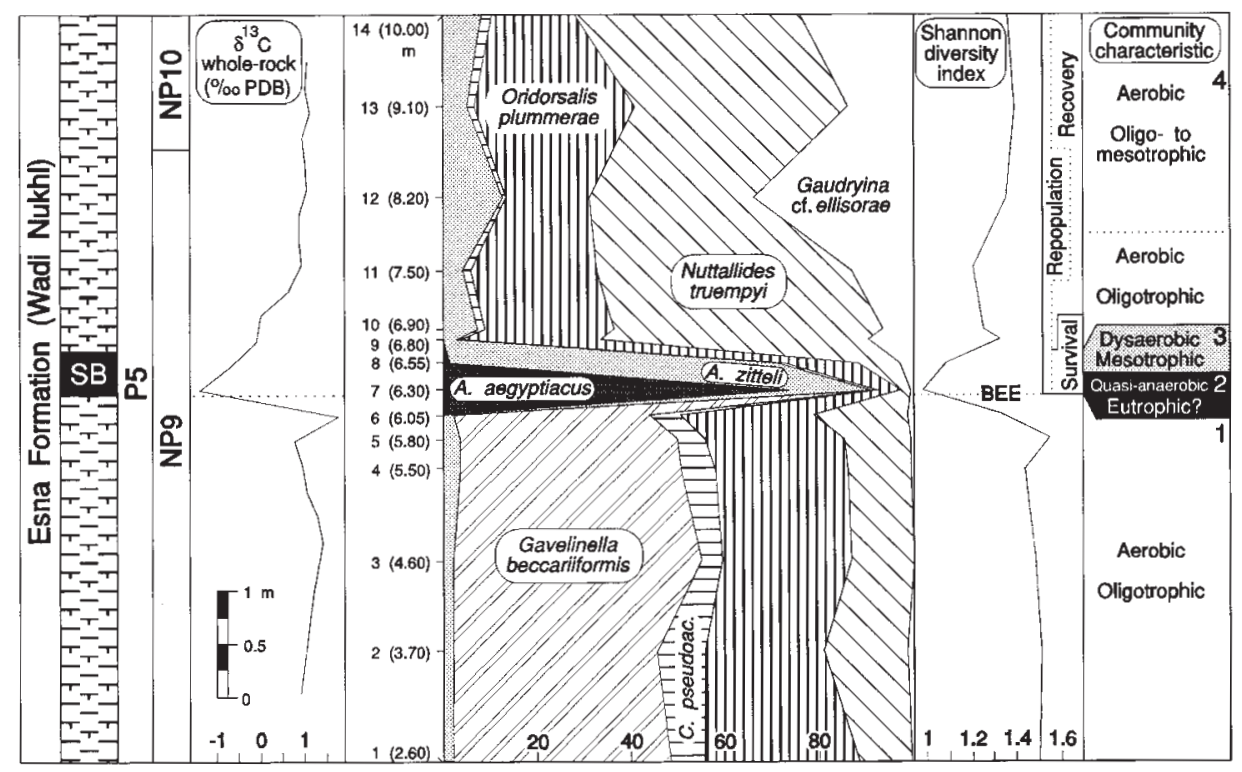

Figure 1. Lithology, stratigraphy, and community development in Wadi Nukhl section. Relative abundance data are given for each taxa group as defined by correspondence analysis (Table 1; denominated by dominant species). Base of sapropelic bed (SB; black, laminated, total organic carbon enriched, and bearing abundant fish scales at base; brown, bioturbated at top) coincides with carbon isotopic excursion and profound biotic changes, including benthic foraminiferal extinction event (BEE). Numbers 1-4 on right side represent stages in community development; community names are indicated with oval frames. Terminology for oxygen regimes and corresponding communities follows recommendations by Tyson and Pearson (1991). Trophic regimes are determined on empirical basis analogous to recent models (e.g., Jorissen et al., 1995). Biozonal notation follows criteria of Berggren et al. (1995). PDB is Peedee belemnite.

Data Repository item 9741 contains additional material related to this article. 
stratigraphy and geologic setting of the Nukhl section, see Speijer (1994). The average sedimentation rate is $\sim 0.6 \mathrm{~cm} / \mathrm{k} . \mathrm{y}$. (time scale of Berggren et al., 1995).

The studied part of the Torangly section spans the lower to upper part of Zone NP9 (corresponding to Zone CP8; N. G. Muzylöv, 1993, written commun.). Planktic foraminifera are rare and poorly preserved, precluding a useful biozonation. The extinction event coincides with the base of the sapropelic bed (Fig. 2) at the CP8a-CP8b zonal boundary (Muzylöv et al., 1995). The top of Zone NP9 is truncated by erosion, thus the average sedimentation rate is estimated as $>1.7 \mathrm{~cm} / \mathrm{k}$.y. Owing to the very small sample sizes, all material was used for foraminiferal studies; stable isotopic data are not available. Because the benthic extinction event and carbon isotopic excursion were synchronous (Kennett and Stott, 1991; Thomas and Shackleton, 1996), we assume that the sapropelic beds are stratigraphic equivalents.

\section{METHODS}

Samples were processed following conventional separation procedures. The $>125 \mu \mathrm{m}$ fraction was used for foraminiferal analysis. Preservation of the Nukhl foraminifera is moderate to good in most samples. However, signs of dissolution (particularly the planktic foraminifera) are observed in the interval below the sapropelic bed, as well as diagenetic alteration and infillings, precluding foraminiferal isotopic analysis. Still, the sequence contains calcareous microfossils throughout and is considered suitable for a quantitative benthic foraminiferal analysis. The 46 most common taxa ${ }^{1}$ (abundance $>2.5 \%$ in one sample or more) were subjected to correspondence analysis and were grouped according to their loadings on the first and second axis (Table 1). Relative abundances for each of the resulting seven taxa groups were calculated (Fig. 1). Whole-rock carbon isotopic data were obtained following the procedures of Charisi and Schmitz (1995).

Foraminiferal preservation of the Torangly samples is very poor owing to severe dissolution and recrystallization, particularly in samples immediately adjacent to the sapropelic bed. Dissolution and a larger terrigenous input than at Nukhl resulted in microbiota occasionally dominated by agglutinated taxa (particularly below the benthic extinction event). Therefore, the results from the Torangly section are based on a semiquantitative survey.

\section{RESULTS}

The correspondence analysis and the plot of relative abundance patterns of the resulting seven

${ }^{1}$ GSA Data Repository item 9741, Abundance data from Wadi Nukhl, is available on request from Documents Secretary, GSA, P.O. Box 9140, Boulder, CO 80301. E-mail: editing@geosociety.org. taxa groups reveal four main stages in latest Paleocene community development at Nukhl: one before and three after the benthic extinction event (Figs. 1 and 3). The G. beccariiformis (up to 17\%) community of stage 1 was highly diverse and stable. All taxa in the G. beccariiformis group (Table 1), accounting for $\sim 40 \%$ of the total microbiota, became extinct during the event. The Anomalinoides aegyptiacus community of stage 2 (A. aegyptiacus: $47 \%$; Stainforthia farafraensis: 27\%) appeared in the laminated lower part of the sapropelic bed and marked an abrupt diversity decline. During stage 3 (upper part of sapropelic bed), the previous community was replaced by the slightly more diverse Anomalinoides zitteli community, including A. zitteli (27\%), Lenticulina spp. (17\%), and Valvulineria scrobiculata (10\%). The $N$. truempyi (up to $29 \%$ ) community of stage 4 was marked by further diversification and decline of the A. zitteli group. The composition of this community varied: the contribution of the Gaudryina cf. ellisorae group fluctuated considerably and covaried with the A. zitteli group. Diversity during stage 4 remained below that of stage 1 .

The Torangly section shows a foraminiferal community sequence (Fig. 3) similar to the Nukhl section. The marlstones below the sapropelic bed contain an assemblage (stage 1) comparable to the G. beccariiformis community of Nukhl, but with a greater proportion of $N$. truempyi, reflecting the greater paleodepth. The laminated base of the sapropelic bed contains no benthic foraminifera (stage 2). Above this horizon are several lowdiversity communities (stage 3): the lowest was dominated by Lenticulina spp. and Bulimina midwayensis, which was replaced by a monospecific Stainforthia sp. community at the top of the sapropelic bed. The overlying marlstones contain a slightly more diverse community, dominated by Lenticulina spp., Bulimina callahani, and B. midwayensis, similar to the $A$. zitteli community at $\mathrm{Nukhl}$, though with a larger proportion of $\mathrm{Bu}$ limina. Typical deep-sea taxa, including $N$. truempyi, are absent in the 3-4 m interval above the base of the sapropelic bed. As deep-sea taxa reappeared, $N$. truempyi tended to dominate the benthic community (stage 4), as in Nukhl.

\section{PALEOECOLOGIC RESPONSE TO REDOX AND TROPHIC CHANGES \\ Wadi Nukhl, Egypt}

The presence of dark laminated sediments and a low-diversity-high-dominance benthic foraminiferal community indicate that there was an oxygen deficiency during deposition of the lower part of the sapropelic bed at Nukhl. This caused the collapse of a highly diverse, aerobic and oligotrophic, G. beccariiformis community (stage 1), which had successfully persisted during the entire Paleocene at Nukhl and is typical of Paleocene deep-sea environments in general. It was replaced by a unique, quasianaerobic community (stage 2), characterized by two opportunistic taxa, A. aegyptiacus and S. farafraensis, typical of a eutrophic, dysoxic middle-neritic environment (Table 1; Speijer et al., 1996). Some modern taxa are rapid recolonizers of a barren benthic environment (e.g., Schafer, 1982; Kaminski et al., 1988; Alve, 1995). For example, Stainforthia fusiformis recolonized a previously anoxic fjord within months after reoxygenation, either through active or passive (juveniles) migration (Alve, 1995). We suggest that $A$. aegyptiacus and $S$. farafraensis repopulated a previously vacated environment from habitats on the shelf in a similar fashion during short-lived and minor improvements of oxygenation at the sea floor. These taxa can be considered as disaster species, typical for the earliest survival phase after mass extinction (Kauffman and Harries, 1996). It is likely that sapropelic deposition, just as for most Pliocene-Holocene sapropels in the Mediterranean (Rohling, 1994), at least in part resulted from increased organic carbon supply to the sea floor. Only the disaster taxa could exploit these richer food resources, facilitated by decreased competition and predation of other microbiota and macrofauna.

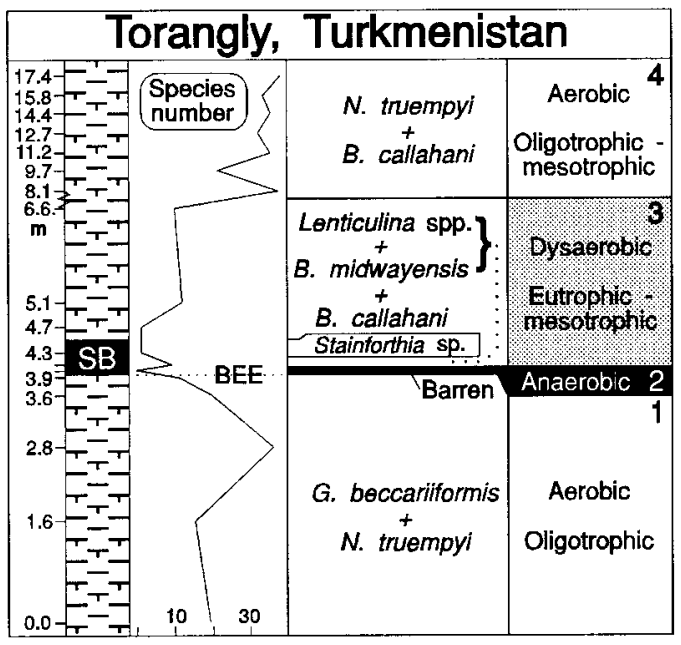

Figure 2. Lithology and community development at Torangly, Turkmenistan. Entire interval belongs to zone NP9 (N. G. Muzylöv, 1993, written commun.). BEE (benthic extinction event) coincides with barren interval at laminated base of sapropelic bed (SB). Low species numbers in samples adjacent to SB (3.9 and $4.7 \mathrm{~m}$ ) result from severe dissolution unlike those within sapropelic bed. Species names indicate most common taxa (excluding agglutinated taxa). Note similarity in community development (stages 1-4) at Wadi Nukhl (Fig. 1). 
The disappearance of both lamination and disaster taxa, as well as the brownish sediment, indicates the return of a better-oxygenated environment during stage 3 . The A. zitteli community consisted of taxa most commonly found in

TABLE I

RESULTS OF CORRESPONDENCE ANALYSIS

\begin{tabular}{|c|c|c|c|}
\hline \multirow[t]{2}{*}{ Taxon } & \multicolumn{3}{|c|}{ Loadings* B.R. } \\
\hline & Ist & 2nd & \\
\hline Stainforthia farafraensis & 4.020 & -0.813 & 1 \\
\hline A nomalinoides aegyptiacus & 3.922 & -0.728 & \\
\hline Loxostomoides applinae & 1.373 & 0.903 & 2 \\
\hline Valvulineria scrobiculata & 1.077 & 1.654 & 1 \\
\hline Anomalinoides zitteli & 0.859 & 1.678 & 2 \\
\hline Lenticulina spp & 0.707 & 0.463 & 2 \\
\hline Osangularia plummerae & 0.363 & 1.131 & 3 \\
\hline Siphogenerinoides spp. & 0.325 & 1.379 & 2 \\
\hline A nomalinoides praeacutus & 0.293 & 1.727 & 2 \\
\hline Bulimina farafraensis & -0.282 & 1.615 & 2 \\
\hline Gaudryina cf. ellisorae & -0.305 & 1.432 & 6 \\
\hline Sporobulimina eocaena & -0.034 & 1.414 & 6 \\
\hline Tritaxia trilatera & -0.271 & 1.291 & 3 \\
\hline Tappanina selmensis & -0.326 & 1.196 & 3 \\
\hline Cibicidoides pharaonis & -0.328 & 1.154 & 3 \\
\hline Globocassidulina subglobosa & -0.079 & 1.143 & 3 \\
\hline Nuttallides truempyi & -0.313 & 0.865 & 5 \\
\hline Bulimina bradbury & -0.348 & 0.838 & 5 \\
\hline Valvulineria sp. 1 & -0.357 & 0.758 & $\mathrm{x}$ \\
\hline A nomalinoides cf rubiginosus & -0.325 & 0.726 & 3 \\
\hline Pullenia spp. & -0.356 & 0.687 & 3 \\
\hline Valvalabamina spp. & -0.277 & 0.537 & 6 \\
\hline Cibicid cf pseudoperlucidus & -0.347 & 0.494 & 3 \\
\hline A nomalinoides affinis & -0.244 & 0.444 & 3 \\
\hline Spiroplectinella esnaensis & -0.283 & 0.396 & 3 \\
\hline Oridorsalis plummerae & -0.222 & 0.201 & 6 \\
\hline Bulimina callahani & -0.317 & 0.106 & 3 \\
\hline Alabamina midwayensis & -0.278 & 0.054 & 6 \\
\hline Cibicidoides alleni & -0.333 & -0.027 & 3 \\
\hline Rest & -0.296 & -0.238 & $\mathrm{x}$ \\
\hline Tritaxia midwayensis & -0.343 & -0.332 & 3 \\
\hline A nomalinoides rubiginosus & -0.284 & -0.655 & 3 \\
\hline Marginulina spp. & -0.430 & -0.915 & $\mathrm{x}$ \\
\hline Cibicidoides pseudoacutus & -0.343 & -1.240 & 3 \\
\hline Nuttallides sp. 1 & -0.470 & -1.487 & 3 \\
\hline Spiroplectinella spectabilis & -0.461 & -1.499 & 4 \\
\hline Gyroidinoides sp. 1 & -0.466 & -1.507 & 5 \\
\hline Karreriella sp. 1 & -0.466 & -1.521 & $\mathrm{x}$ \\
\hline Pullenia conyelli & -0.465 & -1.524 & 5 \\
\hline A nomalinoides cf praeacutus & -0.470 & -1.536 & 5 \\
\hline Hanzow aia cf. caribaea & -0.473 & -1.539 & 3 \\
\hline Gyroidinoides globosus & -0.468 & -1.544 & 4 \\
\hline Gavelinella beccariiformis & -0.470 & -1.558 & 4 \\
\hline Angulogavelinella avnimelechi & $i-0.471$ & -1.572 & 3 \\
\hline Gaudryina nekhlensis & -0.471 & -1.579 & 5 \\
\hline Cibicidoides hyphalus & -0.472 & -1.584 & 5 \\
\hline
\end{tabular}

Notes: *Prinary arrangement and grouping of taxa are according to first-axis loadings; arrangement of taxa with negative loadings on first axis is according to second-axis loadings. Boldface taxa are most common and nominative for each group.

'Bathymetric ranking (B.R.) is based on a compilation of published and unpublished data from Middle East sections and deep-sea cores. $1=$ Exclusively neritic; $2=$ predominantly neritic; $3=$ predominantly outer neritic to bathyal; $4=$

predominantly bathyal; $5=$ exclusively bathyal; 6 $=$ neritic to bathyal: $\mathrm{x}=$ insufficient data middle to outer neritic deposits in Egypt (Table 1; Luger, 1985; Speijer et al., 1995, 1996); at bathyal depths, these taxa are usually rare or absent. Apart from rare N. truempyi, the benthic community was almost identical to outer neritic post-benthic extinction event communities of Gebel Aweina (Speijer et al., 1995), and is considered indicative of mesotrophic, dysoxic conditions. Downslope expansion of a typical neritic community resulted from continued rich food sources during improving ventilation. This interpretation concurs with results of De Stigter (1996), who demonstrated a clear coupling between bathymetric distribution of benthic foraminifera and organic carbon flux in the Adriatic Sea during the late Quaternary. We exclude the possibility that the prevalence of neritic taxa during stages 2 and 3 relates to sea-level fall. There is neither lithologic support for a sharp, $\sim 400 \mathrm{~m}$ sea-level fall that would be required, nor are there indications from neritic sections in Egypt that this region underwent large sea-level fluctuations across the benthic extinction event (Luger, 1985; Speijer et al., 1995, 1996).

Establishment of the $N$. truempyi community during stage 4 marked the restoration of a normal oxic and oligotrophic deep-sea environment at Nukhl. This community consisted of an increasing proportion of equilibrium taxa, although taxa with more opportunistic traits persisted in low numbers. The increasingly important $G$. cf. ellisorae group consisted almost entirely of endobenthic ("infaunal") morphotypes, suggesting improved exploitation of food resources within the sediment (cf. Jorissen et al., 1995). Covarying increases of the G. cf. ellisorae and A. zitteli groups, at the expense of the $N$. truempyi group, suggest intermittent, mesotrophic conditions. Nevertheless, $N$. truempyi was dominant through- out stage 4 , as seen in many post-benthic extinction event deep-sea communities, particularly in the South Atlantic and Indian Ocean (Tjalsma and Lohmann, 1983; Thomas, 1997).

\section{Torangly, Turkmenistan}

Overall community turnover at Torangly was similar to that at Nukhl. An oligotrophic, aerobic deep-sea community collapsed in response to anoxia. Subsequently, deep-sea repopulation progressed through several dysaerobic, mesotrophic to eutrophic communities with strong neritic affinity, largely consisting of more opportunistic and tolerant taxa. Finally, a highly diversified aerobic, oligotrophic-mesotrophic deep-sea benthic community was restored. Yet, in three respects the Torangly sequence is significantly different. Barren conditions preceded the repopulation sequence at Torangly. This difference with Nukhl may simply relate to the higher sample resolution of the Torangly sapropelic bed. Second, the Torangly repopulation sequence is marked by a few abundant Bulimina species. Modern Bulimina species usually occupy a shallow endobenthic microhabitat and may feed more on degraded organic carbon than most epibenthic (epifaunal) taxa (Van der Zwaan et al., 1990; De Stigter, 1996). Considering the much greater proportion of silt- and sand-sized terrigenous particles in the Torangly deposits, the high number of Bulimina could have resulted from laterally transported, degraded organic carbon from the northern Tethyan shelf. Finally, restoration of a normal deep-sea community occurred long after sapropelic deposition at Torangly. Such a delay in community restoration has been noted for some Quaternary sapropels (e.g., Mullineaux and Lohmann, 1981) and could be related to differences in paleoceanographic setting and/or paleodepth.

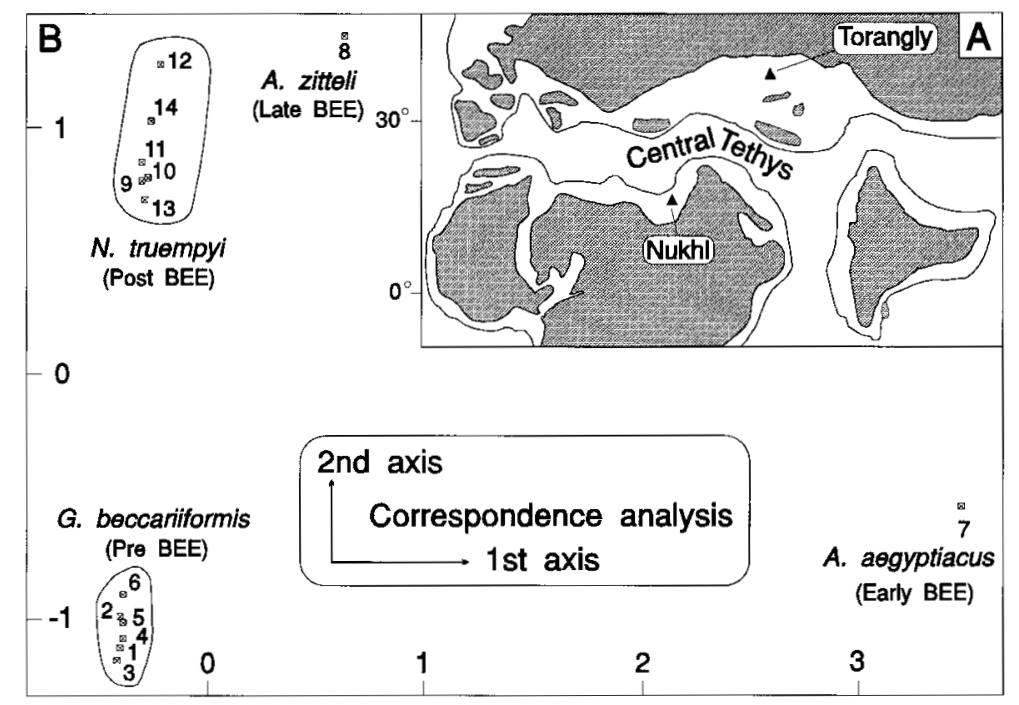

Figure 3. A: Late Paleocene paleogeography of central Tethys. B: Bivariate plot of sample scores on first and second correspondence axes. First two axes explain $\mathbf{4 0} \%$ and $20 \%$, respectively, of total variation. Numbers 1-14 refer to samples. Analysis reveals four different communities, denominated by dominant taxa. 


\section{EXTINCTION AND REPOPULATION IN CENTRAL TETHYS}

Our Tethyan data favor catastrophic over stepwise or graded extinction for the latest Paleocene benthic extinction event. The operative lethal agents, most notably oxygen deficiency, rapidly terminated ( 3-5 k.y. at Torangly) benthic microbiota that had gradually evolved during the Paleocene. A sudden onset of the benthic extinction event is consistent with most other deep-sea studies (e.g., Kennett and Stott, 1991; Kaiho, 1994; Thomas and Shackleton, 1996). Community stages 2 and 3 were composed of taxa with ecologic adaptations typical for an 100-200-k.y.-long survival phase (cf. Kauffman and Harries, 1996).

During the survival phase, previously established bathymetric distributions were erased, and restocking of the bathyal environment progressed through downslope expansion of neritic communities. In this respect, the survival phase is markedly different from oceanic patterns that are typically characterized by in situ survivorship of more opportunistic taxa (such as already present in the Gavelinella beccariiformis community before the benthic extinction event; e.g., Thomas and Shackleton, 1996), not so much by biotic change resulting from migration. Finally, as seafloor conditions ameliorated, diversification and stabilization of community structure during stage 4 marked the transition from the survival to the recovery phase (cf. Kauffman and Harries, 1996). Severely altered deep-sea communities regained their habitat, and neritic communities became restricted to the shelf again.

According to preliminary data by Muzylöv et al. (1995), the uppermost Paleocene sapropelic bed has been encountered in numerous outcrops in the vast area between the Crimea and Tadjikistan on the northern Tethyan margin. It has also been observed at Gebel Qreiya, Egypt (Hendriks et al., 1990). Preliminary benthic foraminifera studies on the Qreiya and the Khieu River section (Caucasus) confirm the tight coincidence between the sapropelic bed and the benthic extinction event. Apparently, the sapropelic bed is an important extinction event-related feature in the central Tethys. We suggest that the repopulation mode documented here could be typical for central Tethyan slope environments.

Widespread sapropelic deposits and our benthic foraminifera data indicate enhanced organiccarbon fluxes in connection with the benthic extinction event in the central Tethys. Similarly, barium enrichment in the extinction event interval suggests high productivity and intensified upwelling at Ben Gurion, Israel (Schmitz et al., 1997). These Tethyan results contrast sharply with concomitant extreme oligotrophic conditions in the tropical Pacific (Kelly et al., 1996), and point to expansion of the trophic resource continuum (Hallock, 1987) during the latest Paleocene environmental and biotic turnover (Thomas, 1997).

\section{ACKNOWLEDGMENTS}

Supported by the Wenner-Gren Foundations and the Bank of Sweden Tercentenary Foundation. We thank N. G. Muzylöv and W. A. Berggren for providing Torangly samples, and R. M. Leckie and L. D. Stott for reviews.

\section{REFERENCES CITED}

Alve, E., 1995, Benthic foraminiferal distribution and recolonization of formerly anoxic environments in Drammensfjord, southern Norway: Marine Micropaleontology, v. 25, p. 169-186.

Berggren, W. A., Kent, D. V., Swisher, C. C., III, and Aubry, M.-P., 1995, A revised Cenozoic geochronology and chronostratigraphy: Society for Economic Paleontologists and Mineralogists Special Publication 54, p. 129-212.

Charisi, S. D., and Schmitz, B., 1995, Stable $\left(\delta^{13} \mathrm{C}\right.$ $\left.\delta^{18} \mathrm{O}\right)$ and strontium $\left({ }^{87} \mathrm{Sr} /{ }^{86} \mathrm{Sr}\right)$ isotopes through the Paleocene at Gebel Aweina, eastern Tethyan region: Palaeogeography, Palaeoclimatology, Palaeoecology, v. 116, p. 103-129.

De Stigter, H. C., 1996, Recent and fossil benthic foraminifera in the Adriatic Sea: Distribution patterns in relation to organic carbon flux and oxygen concentration at the seabed: Geologica Ultraiectina, v. 144, $251 \mathrm{p}$.

Hallock, P., 1987, Fluctuations in the trophic resource continuum; a factor in global diversity cycles? Paleoceanography, v. 2, p. 457-471.

Hendriks, F., Luger, P., and Strouhal, A., 1990, Early Tertiary marine palygorskite and sepiolite neoformation in SE Egypt: Zeitschrift der Deutschen Geologischen Gesellschaft, v. 141, p. 87-97.

Jorissen, F. J., De Stigter, H. C., and Widmark, J. G. V., 1995, A conceptual model explaining benthic foraminiferal microhabitats: Marine Micropaleontology, v. 26, p. 3-15.

Kaiho, K., 1994, Planktonic and benthic foraminiferal extinction events during the last 100 m.y.: Palaeogeography, Palaeoclimatology, Palaeoecology, v. 111, p. $45-71$.

Kaminski, M. A., Grassle, J. F., and Whitlatch, R. B., 1988, Life history and recolonization among agglutinated foraminifera in the Panama Basin: Abhandlungen der Geologischen Bundesanstalt, v. 41, p. 229-244.

Kauffman, E. G., and Harries, P. J., 1996, The importance of crisis progenitors in recovery from mass extinction: Geological Society [London] Special Publication 102, p. 15-39.

Kelly, D. C., Bralower, T. J., Zachos, J. C., PremoliSilva, I., and Thomas, E., 1996, Rapid diversification of planktonic foraminifera in the tropical Pacific (ODP Site 865) during the late Paleocene thermal maximum: Geology, v. 24, p. 423-426.

Kennett, J. P., and Stott, L. D., 1991, Abrupt deep-sea warming, palaeoceanographic changes and benthic extinctions at the end of the Palaeocene: $\mathrm{Na}-$ ture, v. 353, p. 225-229.

Luger, P., 1985, Stratigraphie der marinen Oberkreide und des Alttertiärs im südwestlichen ObernilBecken (SW-Ägypten) unter besonderer Berücksichtigung der Mikropaläontologie, Palökologie und Paläogeographie: Berliner Geowissenschaftliche Abhandlungen, Reihe A: Geologie und Paläontologie, v. 63, $151 \mathrm{p}$.

Mullineaux, L. S., and Lohmann, G. P., 1981, Late Quaternary stagnations and recirculation of the eastern Mediterranean; changes in the deep water recorded by fossil benthic foraminifera: Journal of Foraminiferal Research, v. 11, p. 20-39.
Muzylöv, N. G., Shcherbinina, E. A., Benjamovsky, V. N., Bogolubova, L. I., and Zaporozhetz, N. I., 1995, Preliminary data of the sources of organic matter of the upper Thanetian sapropel layer of the eastern Peritethys: IGCP Project 308 Paleocene/Eocene Boundary Events, Meeting and Field Conference, Beer Sheva, Israel, January 8-15, Abstracts and Field Guide Volume.

Pak, D. K., and Miller, K. G., 1992, Paleocene to Eocene benthic foraminiferal isotopes and assemblages; implications for deep-water circulation: Paleoceanography, v. 7, p. 405-422.

Rohling, E. J., 1994, Review and new aspects concerning the formation of eastern Mediterranean sapropels: Marine Geology, v. 122, p. 1-28.

Schafer, C. T., 1982, Foraminiferal colonization of an offshore dump site in Chaleur Bay, New Brunswick, Canada: Journal of Foraminiferal Research, v. 12, p. 317-326.

Schmitz, B., Speijer, R. P., and Aubry, M.-P., 1996, Latest Paleocene benthic extinction event on the southern Tethyan shelf (Egypt): Foraminiferal stable isotopic $\left(\delta^{13} \mathrm{C}, \delta^{18} \mathrm{O}\right)$ records: Geology, v. 24 , p. $347-350$.

Schmitz, B., Charisi, S. D., Thompson, E. I., and Speijer, R. P., 1997, Barium, $\mathrm{SiO}_{2}$ (excess), and $\mathrm{P}_{2} \mathrm{O}_{5}$ as proxies of biological productivity in the Middle East during the Paleocene and the latest Paleocene benthic extinction event: Terra Nova (in press).

Speijer, R. P., 1994, The late Paleocene benthic foraminiferal extinction as observed in the Middle East: Bulletin de la Société Belge de Géologie, v. 103, p. 267-280.

Speijer, R. P., Schmitz, B., Aubry, M. P., and Charisi, S. D., 1995, The latest Paleocene benthic extinction event: Punctuated turnover in outer neritic foraminiferal faunas from Gebel Aweina, Egypt: Israel Journal of Earth Sciences, v. 44, p. 207-222.

Speijer, R. P., Van der Zwaan, G. J., and Schmitz, B., 1996, The impact of Paleocene/Eocene boundary events on middle neritic benthic foraminiferal assemblages from Egypt: Marine Micropaleontology, v. 28, p. 99-132.

Thomas, E., 1997, The biogeography of the late Paleocene benthic foraminiferal extinction, in Aubry, M.-P., et al., eds., Late Paleocene-early Eocene biotic and climatic events in the marine and terrestrial records: New York, Columbia University Press (in press).

Thomas, E., and Shackleton, N. J., 1996, The PaleoceneEocene benthic foraminiferal extinction and stable isotope anomalies: Geological Society [London] Special Publication 101, p. 401-441.

Tjalsma, R. C., and Lohmann, G. P., 1983, PaleoceneEocene bathyal and abyssal benthic foraminifera from the Atlantic Ocean: Micropaleontology, Special Publication, v. 4, 90 p.

Tyson, R. V., and Pearson, T. H., 1991, Modern and ancient continental shelf anoxia: An overview: Geological Society [London] Special Publication 58, p. 1-24.

Van der Zwaan, G. J., Jorissen, F. J., and De Stigter, H. C., 1990, The depth dependency of planktonic/benthic foraminiferal ratios: Constraints and applications: Marine Geology, v. 95, p. 1-16.

Manuscript received January 14, 1997

Revised manuscript received April 28, 1997

Manuscript accepted May 6, 1997 